\title{
Peripheral Polyneuropathy and Cognitive Impairment in Type II Diabetes Mellitus
}

This article was published in the following Dove Press journal:

Neuropsychiatric Disease and Treatment

\author{
Rasha Elbialy Elsharkawy' \\ Ghada Saed Abdel Azim (D) \\ Marwa Abdellah Osman' \\ Hend Maghraby Maghraby (iD) ${ }^{2}$ \\ Rehab Abdelfattah Mohamed (iD ${ }^{2}$ \\ Eman Mahmoud Abdelsalam (iD) 2 \\ Eman Elshohat Ebrahem ${ }^{3}$ \\ Nora Mohamed Ahmed Seliem (iD) \\ 'Department of Neurology, Faculty of \\ Medicine for Girls, Al-Azhar University, \\ Cairo, Egypt; ${ }^{2}$ Department of Internal \\ Medicine, Faculty of Medicine for Girls, \\ Al-Azhar University, Cairo, Egypt; \\ ${ }^{3}$ Department of Biochemistry, Faculty of \\ Medicine for Girls, Al-Azhar University, \\ Cairo, Egypt
}

Background: Neuropathy is one of most common complications in diabetic patients. Diagnosis of diabetic neuropathy is essential for decreasing the rate of the disability and death. Neuron-specific enolase (NSE) is released from damaged neuronal cells and enters the blood circulation through an injured blood brain barrier. Therefore, serum NSE can reflect the damage of neurons and brain tissue.

Objective: To evaluate peripheral polyneuropathy and cognitive function in Type 2 Diabetes Mellitus (T2DM) and correlate them with NSE level as a possible biomarker of diabetic neuropathy. Subjects and Methods: Forty five T2DM patients with polyneuropathy were randomly recruited in this study compared to 45 healthy age and sex matched subjects as a control. Patients group were divided into two subgroups, 24 diabetic patients with painful peripheral neuropathy and 21 with painless peripheral neuropathy. All were subjected to clinical assessment by diabetic neuropathy symptom score, Dyck neuropathy grading, Mini-Mental State Examination (MMSE), assessment of $\mathrm{HbA1c}$, NSE biomarker and neurophysiological assessment (nerve conduction study (NCS), event related potential (P300wave) and somatosensory evoked potential (SSEP) of the right median nerve).

Results: There were significant decrease in cognitive functions in diabetic patients compared to controls and a significant increase in NSE in diabetic patients. There were no significant difference between patients with painless and painful diabetic neuropathy as regard MMSE, HbA1c and NSE. There were significant correlation of P300 in diabetic patients with HbA1c and NSE.

Conclusion: Neurophysiological assessment of diabetic patients by NCS, SSEP and P300 have well evaluation of cognitive functions, painless, and painful diabetic polyneuropathy. NSE is a beneficial biomarker in diabetic patients to pick up neurological complications.

Keywords: diabetic neuropathy, Mini-Mental State Examination, MMSE, neuron-specific enolase, NSE, nerve conduction study, glycated hemoglobin

\section{Introduction}

$\mathrm{DM}$ is associated with an increased risk of poor cognition and neuro degeneration. Diabetic peripheral neuropathy (DPN) occurs in about $60 \%$ of individuals with longstanding type 1 and type 2 DM. $^{1}$ Evaluating nerve damage through quantification of neuronal derived proteins such as neuron-specific enolase (NSE) facilitate early detection and monitoring of diabetic neurological complications. ${ }^{2}$ Hyperglycemia induces oxidative stress, metabolic abnormalities, disturbance of vascular reactivity, hypoxia, leads to nerve cells damage and release of NSE into the endoneurial fluid and serum. ${ }^{3}$

Neurophysiological measurements are the most commonly tools used to diagnose diabetic sensory motor polyneuropathy (DSPN). ${ }^{4}$ Somatosensory evoked potential (SSEP) are usually used to evaluate the function of large myelinated nerve fibers (A $\beta$ fibers). Short latency somatosensory-evoked potentials are electrical potentials generated
Correspondence: Hend Maghraby Maghraby

Department of Internal Medicine, Faculty of Medicine for Girls, Al-Azhar University, 6 October 3rd Destination, Cairo, 12573 Egypt

Tel +20III49II897

Email drhendms@gmail.com
Neuropsychiatric Disease and Treatment 2021:17 627-635 
at peripheral, spinal, subcortical and cortical levels of the nervous system within the first $60 \mathrm{~ms}$ after electrical stimulation of peripheral nerves. ${ }^{5}$

T2DM can cause dysfunction of the central nervous system, especially cognitive impairment. Individuals with type 2 diabetes are at about $60 \%$ greater risk for the development of dementia compared with equivalents without diabetes. ${ }^{6}$ T2DM has been associated with memory deficits, a decrease in psychomotor speed, and reduced frontal lobe/executive function. Improved glycemic control and decreased diabetic complications may be associated with the prevention of cognitive dysfunction. $^{7}$

The P300 wave is a component of the auditory event related potential (ERP). It is a large positive waveform that reaches a maximum at approximately 300 milliseconds after stimulus onset, which reflects development of cognitive speed. $^{8}$

The aim of this study was to assess the peripheral polyneuropathy and cognitive functions in type II diabetes mellitus and correlate them with serum neuron-specific enolase biomarker for better diagnosis and early management.

\section{Subjects and Methods}

This is a case control study conducted on 45 diabetic patients, who randomly selected between March 2019 and November 2020 from Internal Medicine and Neurology outpatient clinic of Al-Zahraa University Hospital, Cairo, Egypt. 45 healthy age and sex matched subjects were selected as a control group. Diabetic patients divided into two subgroups, group 1a: 21 diabetic patients with painless diabetic polyneuropathy (46.7\%) and group 1b: 24 diabetic patients with painful diabetic polyneuropathy (53.3\%). All the patients met the American Diabetic Association criteria for diabetes diagnosis. 9 This study was followed the principles of the Declaration of Helsinki and was approved by the Institutional Review Board (IRB) of Al-Azhar University (NO: 202,009,371) and written informed consents were obtained from the all participants). Patients with severe renal dysfunction, liver disease, heart failure, known peripheral vascular diseases and autoimmune disease, patients with retinopathy, alcoholism, drug abuse and neurological disease affecting peripheral nerves (eg CIDP, toxins and paraneoplastic syndrome) were excluded. Patient with a history of auditory disorders and psychological disturbances, which might interfere with auditory P300 assessment, were also excluded. Symptoms were documented through the questionnaire.

Diabetic neuropathy symptom score is used to assess neuropathy. Symptoms of somatic and cardioautonomic neuropathy were documented and $A$ score $\geq 1$ considered to be positive. Severity of polyneuropathy was staged according to Dyck neuropathy grading. Grade 0 was defined as no abnormality of NC, Grade 1a = abnormality of NC without symptoms or signs, Grade $1 \mathrm{~b}=\mathrm{NC}$ abnormality of stage 1a plus neurologic signs typical of DSPN but without neuropathy symptoms. Grade $2 \mathrm{a}=\mathrm{NC}$ abnormality of stage 1a with typical neuropathic symptoms. Grade $2 b=\mathrm{NC}$ abnormality of stage 1a, a moderate degree of weakness of ankle dorsiflexion with or without neuropathy symptoms. ${ }^{4}$ Cognitive function is assessed by Mini-Mental State Examination and P300 potential. According to Mini-Mental State Examination, those showing a score of higher than 26 (maximum score $=30$ ) indicating no cognitive impairment, ${ }^{10} \mathrm{P} 300$ show findings if positive waveform reaches a maximum at approximately 300 milliseconds after stimulus onset.

Laboratory investigations including fasting plasma glucose, $\mathrm{HbA} 1 \mathrm{c}$, serum creatinine and urinary albumin concentration were done. Evaluation of serum level of NSE biomarker was assessed by using The CanAg NSE EIA (EMD Millipore, Merck, Germany), which is a solid phase (non-competitive immunoassay based on two monoclonal antibodies (derived from mice) directed against two separate antigenic determinants of the NSE molecule. The monoclonal antibodies (MAb) used bind to the $\gamma$-subunit of the enzyme and thereby detect both the $\gamma \gamma$ and the $\alpha \gamma$ form. The Can Ag NSE EIA is intended for use with serum. Serum should be separated from the clot within 60 minutes of collection to avoid leaking of NSE from blood cells (NSE measurements are compromised by even slight hemolysis, as it is abundant in red blood cells, so haemolysed samples are not used). Plasma is not recommended since significant amounts of NSE can be released from platelets. Samples can be stored at $2-8^{\circ} \mathrm{C}$ for 24 hours. For longer periods store samples at $-70^{\circ} \mathrm{C}$ or below. Healthy individuals are expected to have NSE values below $13 \mu \mathrm{g} / \mathrm{L}$.

Regarding neurophysiological assessment, a nerve conduction study of median nerve (motor, F wave, sensory nerves), ulnar motor nerve and peroneal motor nerve was done using Cadwell sierra wave 8155 certified to CAN ITSA EP/EMG measuring system-4 spaces channels-version 08.11, USA. Additionally, somatosensory evoked potential of the right median nerve and event related potential P300 wave using Neuron Spectrum 5 NeuroMEP.NET for EMG/EP version 3.3.32.0, Russia.

\section{Statistical Methods}

Recorded data were analyzed using the statistical package for social sciences, version 20.0 (SPSS Inc., Chicago, IL, 
USA). The qualitative variables were described as frequencies and percentages. The quantitative data were described by the means and standard deviations (SDs) and were compared by independent $t$-test. Non-parametric variables were expressed as medians and were compared by using the Mann-Whitney U-test. Also the comparison between more than two independent groups one-way analysis of variance (ANOVA) for parametric data and Kruskal-Wallis test for non-parametric data. Spearman correlation analysis was used to assess the degree of association between two sets of variables. The receiver operating characteristics (ROC) were used to evaluate the sensitivity and specificity of NSE. The confidence interval was set to $95 \%$ and the margin of error accepted was set to $5 \%$. So, $P$-value $\leq 0.05$ was considered significant.

\section{Results}

This study was conducted on 45 T2DM patients with neuropathy and 45 healthy subjects. The demographic clinical and laboratory data of the participants are listed in Table 1. There were significant decrease in cognitive function in patient group compared to control assessed by MMSE and P300 latency with significant increase in HbA1c and NSE in diabetic patients (Table 2, Figure 1).

As regard nerve conduction examination, there were statistically significant decrease in nerve conduction velocity of examined nerves (Rt median, Rt ulnar and Rt peroneal) in diabetic patients compared to control (Table 3). Also, there were statistically significant difference between patients and control groups as regard proximal nerve conduction (N9) and central conduction time (CC1 \& CC2) (Table 4).

On comparing the grades of neuropathy by Dyke neuropathy grading, there were significant increase in median of disease duration, serum NSE and mean HbA1c levels in patients with moderate neuropathy (Grade 2b) compared to groups of mild neuropathy or asymptomatic cases (Grade Ia, Ib, 2a) (Table 5). There were significant difference in P300 in diabetic patients with painless neuropathy compared to those with painful neuropathy, while there were no significant difference in MMSE, HbA1c and NSE between the 2 groups (Table 6, Figure 2). Right common peroneal nerve more affected in painless diabetic neuropathy while the latency of $\mathrm{F}$ wave of right median nerve more affected in those with painful neuropathy (Table 7).

For assessment of mental state affection in diabetic patients, we found that there were positive significant
Table I Demographic and Clinical Data of Studied Groups

\begin{tabular}{|c|c|c|}
\hline & Diabetic Patients $(n=45)$ & Control $(n=45)$ \\
\hline Age (years) & $26-60$ & $27-59$ \\
\hline Sex (male/female) & $20 / 25$ & $23 / 22$ \\
\hline $\begin{array}{l}\text { Disease duration (years) } \\
\text { Range } \\
\text { Median (IQR) }\end{array}$ & $\begin{array}{l}5-25 \\
11(8-16)\end{array}$ & - \\
\hline $\begin{array}{l}\text { Systolic BP }(\mathrm{mmHg}) \\
\text { Range }\end{array}$ & $120-145$ & $110-135$ \\
\hline $\begin{array}{l}\text { BMI }\left(\mathrm{kg} / \mathrm{m}^{2}\right) \\
\text { Range }\end{array}$ & $21-35.6$ & $20-38.4$ \\
\hline $\begin{array}{l}\mathrm{FBS}(\mathrm{mg} / \mathrm{dL}) \\
\text { Range }\end{array}$ & $125-300$ & $80-110$ \\
\hline $\begin{array}{l}\mathrm{HbAlc}(\%)(\mathrm{mmol} / \mathrm{mol}) \\
\quad \text { Range } \\
\text { Mean } \pm \mathrm{SD}\end{array}$ & $\begin{array}{l}6.47-9.91 \\
8.20 \pm 1.18\end{array}$ & $\begin{array}{l}3.96-5.63 \\
5.01 \pm 0.45\end{array}$ \\
\hline $\begin{array}{l}\text { NSE }(\mu g / \mathrm{L}) \\
\text { Range } \\
\text { Median (IQR) }\end{array}$ & $\begin{array}{l}9.57-200 \\
37(22-78)\end{array}$ & $\begin{array}{l}6.87-33.1 \\
10(7-16)\end{array}$ \\
\hline $\begin{array}{l}\text { MMS } \\
\text { Range } \\
\text { Mean } \pm S D\end{array}$ & $\begin{array}{l}23-30 \\
26.60 \pm 2.1\end{array}$ & $\begin{array}{l}27-30 \\
29.07 \pm 0.48\end{array}$ \\
\hline $\begin{array}{l}\text { P300 } \\
\text { Range } \\
\text { Median }\end{array}$ & $\begin{array}{l}237-422 \\
322(293-385)\end{array}$ & $\begin{array}{l}207-320 \\
278(251-295)\end{array}$ \\
\hline Neurological deficit in di & tic patients & \\
\hline Distal weakness & $\begin{array}{l}\text { Group la } \\
\text { Group lb }\end{array}$ & $\begin{array}{l}2(9 \%) \\
2(8.3 \%)\end{array}$ \\
\hline Hyporeflexia & $\begin{array}{l}\text { Group la } \\
\text { Group lb }\end{array}$ & $\begin{array}{l}12(57.1 \%) \\
19(79.2 \%)\end{array}$ \\
\hline Hyposethesia & $\begin{array}{l}\text { Group la } \\
\text { Group lb }\end{array}$ & $\begin{array}{l}18(85.7 \%) \\
24(100 \%)\end{array}$ \\
\hline Lost vibration & $\begin{array}{l}\text { Group la } \\
\text { Group lb }\end{array}$ & $\begin{array}{l}19(90.5 \%) \\
9(37.5 \%)\end{array}$ \\
\hline
\end{tabular}

Abbreviations: BMI, body mass index; NSE, neuron-specific enolase; MMS, MiniMental State.

correlation of P300 with NSE and negative correlation with MMS in diabetic patients. There were no statistically significant correlation of P300 with disease duration and HbA1c (Table 8, Figure 3). The cutoff point of serum NSE $>12.6$ with $88 \%$ sensitivity (Table 9, Figure 4).

\section{Discussion}

Diabetic neuropathy is the most common complication of DM, affecting $50 \%$ of patients with T2DM. Diabetic 
Table 2 Comparison Between Diabetic Patients (Group I) and Control (Group II) as Regard Mini-Mental State Examination (MMS), Hemoglobin AIC (HbAIc), Neuron-Specific Enolase (NSE) and P300 Latency

\begin{tabular}{|l|l|l|l|l|}
\hline & Group I & Group II & Test value & P-value \\
\hline MMS & $26.60 \pm 2.1$ & $29.07 \pm 0.48$ & $-10.968^{*}$ & $<0.001$ \\
HbAlc & $8.20 \pm 1.18$ & $5.01 \pm 0.45$ & $16.92 I^{*}$ & $<0.001$ \\
NSE & $37(22-78)$ & $10(7-16)$ & $4.857^{\neq}$ & $<0.001$ \\
P300 & $332(293-385)$ & $278(25 I-295)$ & $5.432^{\neq}$ & $<0.001$ \\
\hline
\end{tabular}

Notes: *Independent $t$-test; ${ }^{\neq}$Mann-Whitney test.

neuropathy is a misnomer, affects the entire central nervous system and involves the peripheral nerves, the spinal cord and the thalamus. ${ }^{11}$ About $80 \%$ of the cases of DN manifest as distal symmetrical sensorimotor polyneuropathy, which is associated with chronic pain, impaired sleep quality, increased falling risk and increase of the risk of extremities amputation. ADA guidelines recommended an annual clinical screening to diagnose sensitive diabetic neuropathy. ${ }^{12}$

In the current study, clinical neurological examination of diabetic patients revealed that vibration sense significantly lost in $(90.5 \%)$ of diabetic patients with painless neuropathy. This is in agreement with the study done by Jianbo, ${ }^{3}$ who concluded that physical examination is the most useful tool in evaluating large fiber peripheral neuropathy (LFPN) in diabetic patients. Abnormal results on monofilament testing and vibratory perception (alone or associated with the presence of the feet ulceration and ankle reflexes) are the most helpful signs.

In this study, we found Dyck neuropathy grading progression associated with increase in duration of

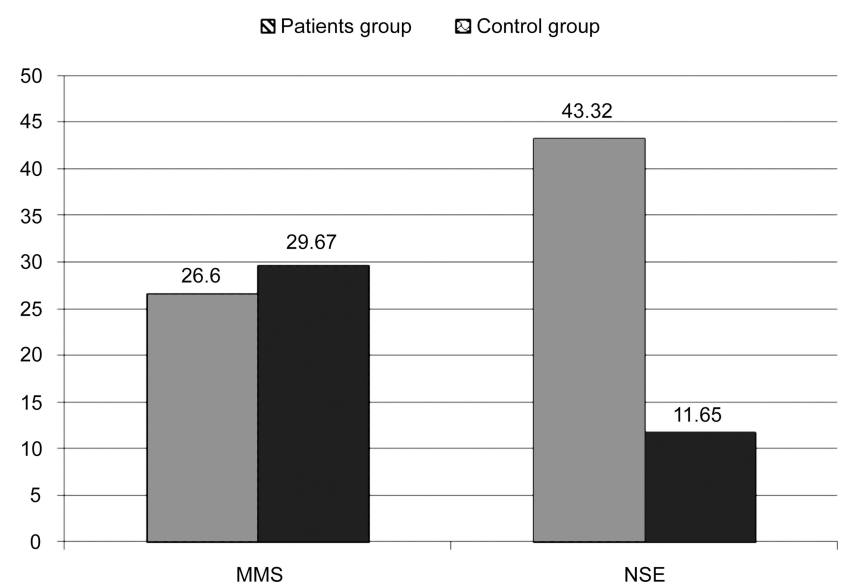

Figure I Mean level of neuron-specific enolase (NSE) increased in diabetic patients group compared to control. Mean score of Mini-Mental State Examination (MMSE) was decreased in diabetic patients compared to control. illness and $\mathrm{HbAlc}$. A study by Sorensen et $\mathrm{al}^{13}$ found that glycated $\mathrm{Hb}$ and duration of illness are dependent risk factors of diabetic neuropathy. Also, Smith and Singleton, ${ }^{14}$ who examined 218 subjects with T2DM without neuropathy symptoms or with symptoms of less than 5 years duration, found a significant relationship between duration of illness, glycemic control and neuropathy status. Hyperglycemia may have differential effects on small vs large fibers. Chronic hyperglycemia can cause nerve affection by activation of the polyol pathway, reactive oxygen species (ROS) and through the accumulation of advanced glycation end products (AGE) that activate inflammatory cascades. ${ }^{15}$ In this study we found that in both diabetic patients group (with painless and painful neuropathy), peroneal nerve is more affected than the median nerve in all parameters (symptoms, signs, and conduction study). Inconsistent with the current study, Karsidag et al ${ }^{16}$ stated that the lower extremity nerves, mostly sural and peroneal nerves followed by the right posterior tibial nerve, were affected earlier and more commonly than other nerves.

In this study we found that somatosensory evoked potential (SEP) of right median nerve were significantly affected in patients with diabetes compared to control in both proximal peripheral conduction (N9) and central conduction (CCT1 \& CCT2) but CCT1 \& $\mathrm{CCT} 2$ were more affected than $\mathrm{N} 9$ meaning that central abnormality is not due to slowness of the peripheral sensory conduction.

Also other studies reported a similar percentage of abnormal SSEP in patients without clinical manifestations of polyneuropathy, which may suggest that the peripheral and the central nervous systems are affected independently in patients with diabetes. ${ }^{17,18}$

In this study we found that P300 latency as a test for cognition was significantly affected more in 
Table 3 Comparison Between Diabetic Patients (Group I) and Control (Group II) as Regard Distal Latency, Amplitude, and Conduction Velocity of Right Median Motor, Sensory \& F Wave, Right Ulnar and Right Common Peroneal Motor Nerves

\begin{tabular}{|c|c|c|c|c|c|}
\hline & & Range & Mean $\pm S D$ & $t$-test & $P$-value \\
\hline \multicolumn{6}{|l|}{ Rt median nerve } \\
\hline Distal latency & $\begin{array}{l}\text { Group I } \\
\text { Group II }\end{array}$ & $\begin{array}{l}2.9-7.6 \\
2.7-3.9\end{array}$ & $\begin{array}{l}4.68 \pm 1.10 \\
3.27 \pm 0.39\end{array}$ & 8.132 & $<0.001$ \\
\hline Amplitude & $\begin{array}{l}\text { Group I } \\
\text { Group II }\end{array}$ & $\begin{array}{l}1-10.3 \\
4.9-6.20\end{array}$ & $\begin{array}{l}4.49 \pm 2.09 \\
5.54 \pm 0.42\end{array}$ & -3.308 & $<0.001$ \\
\hline CV & $\begin{array}{l}\text { Group I } \\
\text { Group II }\end{array}$ & $\begin{array}{l}33-79 \\
59-79\end{array}$ & $\begin{array}{l}46.63 \pm I I .23 \\
58.00 \pm 5.58\end{array}$ & -6.060 & $<0.001$ \\
\hline \multicolumn{6}{|l|}{ Rt ulnar nerve } \\
\hline Distal latency & $\begin{array}{l}\text { Group I } \\
\text { Group II }\end{array}$ & $\begin{array}{l}2.3-10.6 \\
2.4-3.6\end{array}$ & $\begin{array}{l}4.17 \pm 1.89 \\
3.04 \pm 0.35\end{array}$ & 3.921 & $<0.001$ \\
\hline Amplitude & $\begin{array}{l}\text { Group I } \\
\text { Group II }\end{array}$ & $\begin{array}{l}1.6-7.6 \\
3.5-6\end{array}$ & $\begin{array}{l}4.12 \pm 1.30 \\
4.89 \pm 0.84\end{array}$ & -3.302 & $<0.001$ \\
\hline CV & $\begin{array}{l}\text { Group I } \\
\text { Group II }\end{array}$ & $\begin{array}{l}20-79 \\
50-65\end{array}$ & $\begin{array}{l}53.30 \pm 9.84 \\
56.80 \pm 4.69\end{array}$ & -1.837 & $<0.05$ \\
\hline \multicolumn{6}{|l|}{ Rt peroneal nerve } \\
\hline Distal latency & $\begin{array}{l}\text { Group I } \\
\text { Group II }\end{array}$ & $\begin{array}{l}4.1-20.4 \\
2-2.5\end{array}$ & $\begin{array}{l}8.53 \pm 3.92 \\
2.23 \pm 0.18\end{array}$ & 10.842 & $<0.001$ \\
\hline Amplitude & $\begin{array}{l}\text { Group I } \\
\text { Group II }\end{array}$ & $\begin{array}{l}0-3.90 \\
3.5-4.5\end{array}$ & $\begin{array}{l}1.95 \pm 1.10 \\
3.87 \pm 0.31\end{array}$ & -10.937 & $<0.001$ \\
\hline CV & $\begin{array}{l}\text { Group I } \\
\text { Group II }\end{array}$ & $\begin{array}{l}0-49 \\
40-50\end{array}$ & $\begin{array}{l}39.82 \pm 8.35 \\
45.33 \pm 3.32\end{array}$ & -3.871 & $<0.001$ \\
\hline Rt. median sensory nerve latency & $\begin{array}{l}\text { Group I } \\
\text { Group II }\end{array}$ & $\begin{array}{l}2.1-6.5 \\
2.9-3.5\end{array}$ & $\begin{array}{l}4.70 \pm 1.30 \\
3.13 \pm 0.19\end{array}$ & 7.946 & $<0.001$ \\
\hline RT median $\mathrm{F}$ wave latency & $\begin{array}{l}\text { Group I } \\
\text { Group II }\end{array}$ & $\begin{array}{l}15-45 \\
22-30\end{array}$ & $\begin{array}{l}30.48 \pm 7.06 \\
26.07 \pm 2.62\end{array}$ & 3.841 & $<0.001$ \\
\hline
\end{tabular}

Table 4 Comparison Between Diabetic Patients (Group I) and Control (Group II) as Regards Somatosensory Evoked Potential of Right Median Nerve

\begin{tabular}{|c|c|c|c|c|c|}
\hline Variables & Studied Group & Range & Mean士SD & $t$-test & $P$-value \\
\hline N9 & $\begin{array}{l}\text { Group I } \\
\text { Group II }\end{array}$ & $\begin{array}{l}7.85-11.9 \\
7.45-9.95\end{array}$ & $\begin{array}{l}9.51 \pm 0.53 \\
9.17 \pm 0.42\end{array}$ & 2.249 & $<0.05$ \\
\hline $\mathrm{CCl}$ & $\begin{array}{l}\text { Group I } \\
\text { Group II }\end{array}$ & $\begin{array}{l}1-4.5 \\
1.2-2.2\end{array}$ & $\begin{array}{l}2.54 \pm 0.98 \\
1.69 \pm 0.30\end{array}$ & 5.514 & $<0.001$ \\
\hline $\mathrm{CC} 2$ & $\begin{array}{l}\text { Group I } \\
\text { Group II }\end{array}$ & $\begin{array}{l}3.94-12.4 \\
4.7-6.15\end{array}$ & $\begin{array}{l}6.86 \pm 2.02 \\
5.57 \pm 0.41\end{array}$ & 4.194 & $<0.001$ \\
\hline
\end{tabular}

Notes: N9: proximal nerve conduction. CCI\&CC2: central conduction time. 
Table 5 Comparison Between Dyck Neuropathy Grading ( Ia, Ib, 2a, and 2b) in Diabetic Patients as Regard Duration of IIIness, $\mathrm{HbAlc}$ and NSE

\begin{tabular}{|c|c|c|c|c|c|c|}
\hline & Ia $(n=I)$ & Ib $(n=\mid 8)$ & $2 a(n=22)$ & $2 b(n=4)$ & Test Value & $P$-value \\
\hline Duration of illness Median (IQR) & $6(6-6)$ & $8(3-11)$ & $9(4-15)$ & $12(7-16)$ & $5.685^{\neq}$ & 0.002 \\
\hline HbAlc Mean \pm SD & $7.82 \pm 0.00$ & $7.85 \pm 1.28$ & $9.37 \pm 0.46$ & $9.37 \pm 0.46$ & $10.548^{*}$ & $<0.001$ \\
\hline NSE Median (IQR) & $37.9(37.9-37.9)$ & $42.2(11.5-65.3)$ & $52.9(22.8-68.4)$ & $72.3(45.6-115.6)$ & $7.513^{\neq}$ & $<0.001$ \\
\hline
\end{tabular}

Notes: * One Way ANOVA test, ${ }^{\neq}$Kruskal-Wallis test.

Table 6 Comparison Between Patients with Painless (Group la) and Painful (Group lb) Diabetic Neuropathy as Regard MMS, HbAlc and NSE

\begin{tabular}{|c|c|c|c|c|}
\hline & Group la $(n=2 I)$ & Group Ib $(n=24)$ & Test Value & $P$-value \\
\hline \multicolumn{5}{|l|}{ MMS } \\
\hline Range & $24-30$ & $24-30$ & $0.073^{*}$ & $>0.05$ \\
\hline Mean \pm SD & $26.62 \pm 1.86$ & $26.58 \pm 1.82$ & & \\
\hline \multicolumn{5}{|l|}{$\mathrm{HbAlc}$} \\
\hline Range & $6.16-9.91$ & $5.74-9.87$ & $1.256 *$ & $>0.05$ \\
\hline Mean \pm SD & $8.43 \pm 0.99$ & $7.99 \pm 1.31$ & & \\
\hline \multicolumn{5}{|l|}{ NSE } \\
\hline Range & $10.7-170.3$ & $9.75-200$ & $0.265 \neq$ & $>0.05$ \\
\hline Median (IQR) & $38.6(22.8-73.5)$ & $32.5(18.9-68.6)$ & & \\
\hline \multicolumn{5}{|l|}{ P300 } \\
\hline Range & $237-422$ & $256-416$ & $2.174 \neq$ & 0.03 \\
\hline Median (IQR) & $344(285-377)$ & $296(278-34 I)$ & & \\
\hline
\end{tabular}

Notes: *Independent $t$-test; ${ }^{\ddagger}$ Mann-Whitney test.

diabetic patients compared to controls. Also Hamed et $\mathrm{al}^{19}$ stated that the risk of cognitive dysfunction increases with T2DM, as confirmed by low scores of cognitive testing and poor performance in different

P300

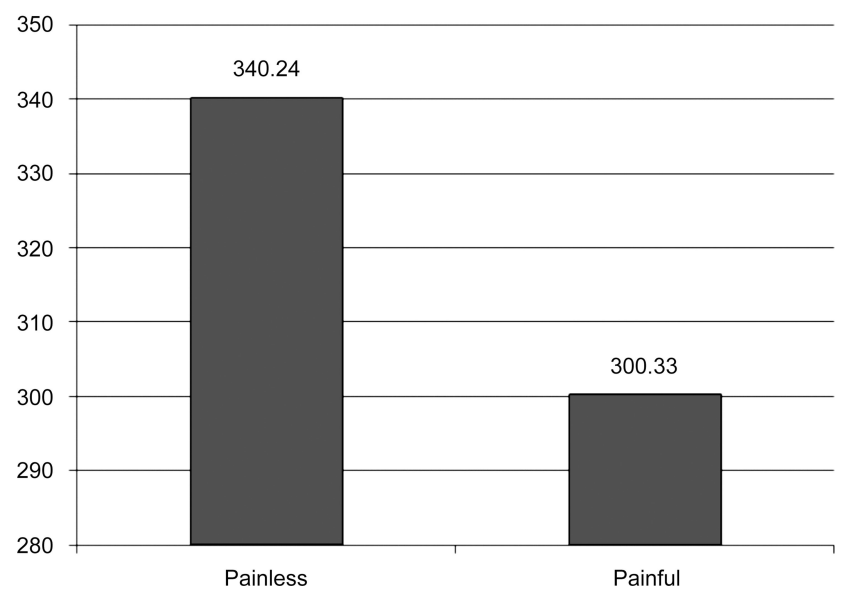

Figure 2 P300 waves increased in diabetic patients with painless neuropathy (Group la) compared to diabetic patients with painful neuropathy (Group Ib). cognitive tasks in T2DM patients compared to controls. DM subjects had lower cognitive function compared to non-DM subjects. Slow gait speed and hyperglycemia were associated with a wide-range of cognitive domains, but mostly executive function. ${ }^{20}$

In this study, we found that P300 increase in latency in patients with painless neuropathy compared to painful diabetic neuropathy. This agree with Mc Crimmon et $\mathrm{al}^{21,22}$ and Ryan et al, who found the difference observed in painless vs painful diabetic group with greater reduction in thalamic volume in the painless group compared with the painful group. This finding is consistent with previous magnetic resonance spectroscopy report of increased thalamic neuronal dysfunction in subjects in the painless DPN group but not in the painful DPN group. ${ }^{21}$ This may explain that P300 latency difference between the two groups because thalamus has a role in memory in painless group associated with more risk of microvascular complication, and so more cognitive impairment. 
Table 7 Comparison Between Patients with Painless (Group la) and Painful (Group lb) Diabetic Neuropathy as Regard Distal Latency, Amplitude and Conduction Velocity of Right Motor Median, Ulnar and Common Peroneal Nerves, Right Median Sensory Nerve and $\mathrm{F}$ Wave Latencies

\begin{tabular}{|c|c|c|c|c|c|}
\hline Nerve Conduction & Studied Group & Range & Mean士SD & $t$-test & $P$-value \\
\hline \multicolumn{6}{|l|}{ Rt. median nerve } \\
\hline Distal latency & $\begin{array}{l}\text { Group la } \\
\text { Group lb }\end{array}$ & $\begin{array}{l}3.4-7.6 \\
2.9-7.5\end{array}$ & $\begin{array}{l}4.67 \pm 1.15 \\
4.69 \pm 1.08\end{array}$ & -0.056 & $>0.05$ \\
\hline Amplitude & $\begin{array}{l}\text { Group la } \\
\text { Group lb }\end{array}$ & $\begin{array}{l}1.1-7.2 \\
1-10.3\end{array}$ & $\begin{array}{l}4.2 I \pm I .7 \mid \\
4.70 \pm 2.35\end{array}$ & -0.740 & $>0.05$ \\
\hline $\mathrm{CV}$ & $\begin{array}{l}\text { Group la } \\
\text { Group lb }\end{array}$ & $\begin{array}{l}34-59 \\
33-79\end{array}$ & $\begin{array}{l}43.58 \pm 12.04 \\
49.04 \pm 10.14\end{array}$ & -1.615 & $>0.05$ \\
\hline \multicolumn{6}{|l|}{ Rt ulnar nerve } \\
\hline Distal latency & $\begin{array}{l}\text { Group lb } \\
\text { Group la }\end{array}$ & $\begin{array}{l}2.6-10.6 \\
2.3-10.6\end{array}$ & $\begin{array}{l}4.28 \pm I .8 I \\
4.07 \pm 1.99\end{array}$ & 0.364 & $>0.05$ \\
\hline Amplitude & $\begin{array}{l}\text { Group lb } \\
\text { Group la }\end{array}$ & $\begin{array}{l}1.6-6.3 \\
2-7.3\end{array}$ & $\begin{array}{l}4.19 \pm 1.38 \\
4.06 \pm 1.27\end{array}$ & 0.314 & $>0.05$ \\
\hline$C V$ & $\begin{array}{l}\text { Group lb } \\
\text { Group la }\end{array}$ & $\begin{array}{l}30-72 \\
20-79\end{array}$ & $\begin{array}{l}51.63 \pm 10.38 \\
54.63 \pm 12.95\end{array}$ & -0.820 & $>0.05$ \\
\hline \multicolumn{6}{|l|}{ Rt peroneal nerve } \\
\hline Distal latency & $\begin{array}{l}\text { Group la } \\
\text { Group lb }\end{array}$ & $\begin{array}{l}4.1-20.4 \\
4.3-11.6\end{array}$ & $\begin{array}{l}10.81 \pm 6.19 \\
7.47 \pm 1.70\end{array}$ & 1.991 & $>0.05$ \\
\hline Amplitude & $\begin{array}{l}\text { Group la } \\
\text { Group lb }\end{array}$ & $\begin{array}{l}0-3.3 \\
0-3.9\end{array}$ & $\begin{array}{l}1.47 \pm 1.09 \\
2.17 \pm 1.07\end{array}$ & 2.170 & $<0.05$ \\
\hline $\mathrm{CV}$ & $\begin{array}{l}\text { Group la } \\
\text { Group lb }\end{array}$ & $\begin{array}{l}0-49 \\
0-48\end{array}$ & $\begin{array}{l}36.43 \pm 11.97 \\
41.40 \pm 5.90\end{array}$ & -1.323 & $>0.05$ \\
\hline Rt. median sensory latency & $\begin{array}{l}\text { Group la } \\
\text { Group lb }\end{array}$ & $\begin{array}{l}2.3-6.5 \\
2.1-6.3\end{array}$ & $\begin{array}{l}4.50 \pm 1.65 \\
4.79 \pm 1.14\end{array}$ & -0.513 & $>0.05$ \\
\hline RT median F wave latency & $\begin{array}{l}\text { Group la } \\
\text { Group lb }\end{array}$ & $\begin{array}{l}18.3-39 \\
15-45\end{array}$ & $\begin{array}{l}28.22 \pm 5.86 \\
32.88 \pm 8.04\end{array}$ & 2.194 & $<0.05$ \\
\hline
\end{tabular}

P300 latency was significantly correlated with serum level of NSE in diabetic patients enrolled in this study. Also Hamed et $\mathrm{al}^{19}$ found that there was a significant correlation between level of NSE and poor performance of cognitive function including P300.

Table 8 Correlation Between P300 and Duration of Illness, MMS, HbAlc and NSE in Diabetic Patients

\begin{tabular}{|l|l|l|}
\hline \multirow{2}{*}{} & \multicolumn{2}{|l|}{ P300 } \\
\cline { 2 - 3 } & r & P-value \\
\hline Duration of illness & -0.217 & $>0.05$ \\
MMS & -0.516 & $<0.001$ \\
HbAIc & -0.733 & $<0.001$ \\
NSE & 0.789 & $<0.001$ \\
\hline
\end{tabular}

NSE has been implicated in ischemia, hypoxia, diverse metabolic, proliferative, inflammatory, autoimmune, and neurodegenerative diseases. A progressive loss of

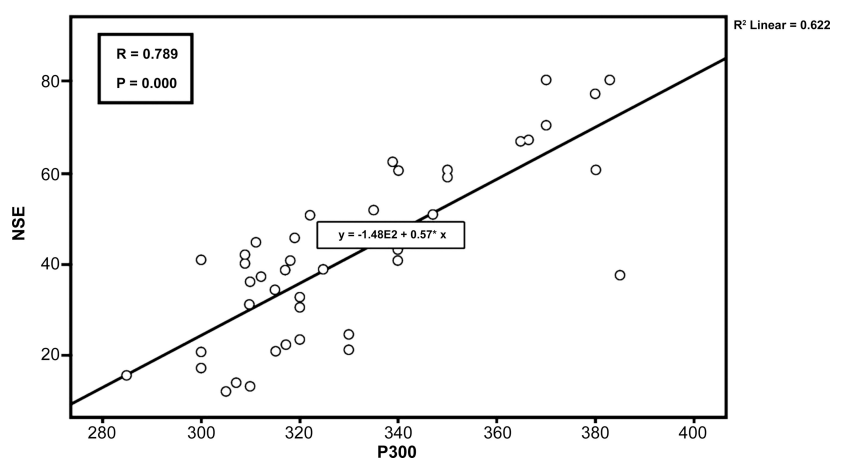

Figure 3 Scatter plot of the relationship between P300 and neuron-specific enolase (NSE), $P<0.001$. 


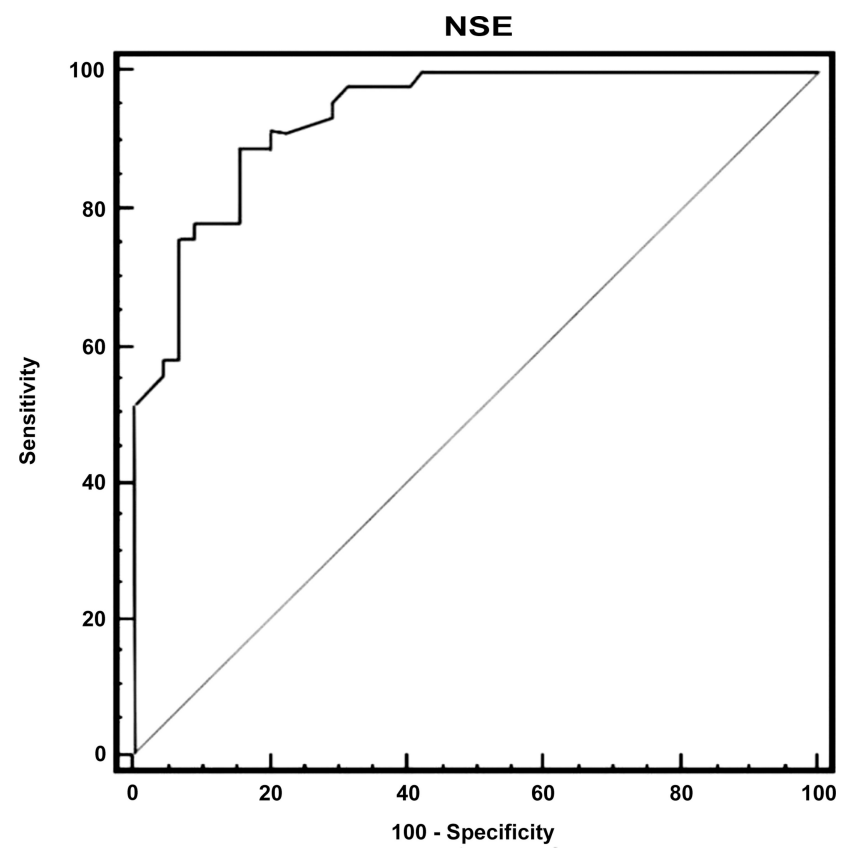

Figure 4 ROC data of neuron-specific enolase (NSE) in diabetic patients vs control.

neurons and synapses are common features of neurodegenerative disorders, where the degree of neuronal loss correlates with increased levels of NSE in serum and CSF and clinical progression of the disease. ${ }^{23}$

In the current study, P300 had no significant correlation with duration of disease in diabetic patients. Conversely, there was a positive correlation between prolongation of latencies and duration of DM reported by Harini and Bahagya. $^{24}$

In conclusion, our data denote that a brief cognition evaluation could be important in assessing the impact of diabetes on the mental health. Evoked response potentials seem to be good at detecting sensory/perception deficits in diabetic patients. P300 can easily detect subclinical cognitive impairment before appearance of any neurological manifestations. NSE is a predictor for both central and peripheral nervous system in T2DM. It is important to perform a detailed clinical examination, in order to early diagnose diabetes-related neurological and cognitive dysfunction.

Table 9 ROC Curve of Neuron-Specific Enolase (NSE)

\begin{tabular}{|l|l|l|l|l|}
\hline Cutoff Point & AUC & Sensitivity & +PV & -PV \\
\hline$>12.6$ & 0.935 & 88.89 & 85.1 & 88.4 \\
\hline
\end{tabular}

\section{Funding}

There is no funding to report.

\section{Disclosure}

The authors declared no conflicts of interest in this work.

\section{References}

1. Ali A, Iqbal F, Taj A, Iqbal Z. Prevalence of microvascular complications in newly diagnosed patients with type 2 diabetes. Pak J Med Sci. 2013;29:899-902. doi:10.12669/pjms.294.3704

2. Kiernan C. Emergence of a predictive clinical biomarker for diabetic neuropathy. J Diab. 2012;61(6):1346-1347. doi:10.2337/db12-0193

3. Jianbo LI. NSE potential biomarker is closely connected to diabetic peripheral neuropathy. Diab Care. 2013;36(11):3405-3410.

4. Dyck P, Carter R, Litchy W. Modeling nerve conduction criteria for diagnosis of diabetic polyneuropathy. Muscle Nerve. 2011;44:340345. doi: $10.1002 /$ mus. 22074

5. Shin H, Gong H, Oh J, Paik N. Comparison between nerve conduction studies and current perception threshold test in carpal tunnel syndrome. Neurophysiol Clin. 2008;38:127-131. doi:10.1016/j. neucli.2007.12.003

6. Chatterjee S, Peters SA, Woodward M, et al. Type 2 diabetes as a risk factor for dementia in women compared with men: A pooled analysis of 2.3 million people comprising more than 100,000 cases of dementia. Diab Care. 2016;39:300-307. doi:10.2337/dc15-1588

7. Kim H-G. Cognitive dysfunctions in individuals with diabetes mellitus. Yeungnam Univ J Med. 2019;36(3):183-191. doi:10.12701/ yujm.2019.00255

8. Van Dinteren R, Arns M, Jongsma MLA, Kessels RPC. P300 development across the lifespan: a systematic review and meta-analysis. PLoS One. 2014;9(2):e87347. doi:10.1371/journal.pone.0087347

9. American Diabetes Association. Standards of medical care in diabetes-2015. Diab Care. 2015;38(1):S1-93. Epub 2014/12/30

10. Folstein MF, Folstein SE, McHugh PR. Mini-mental state. A practical method for grading the cognitive state of patients for the clinician. $J$ Psychiatr Res. 1975;12(3):189-198. doi:10.1016/0022-3956(75)90026-6

11. Tesfaye S Diabetic neuropathy: a journey with tears, passion, new insights and a paradigm shift. Program and abstracts of the European Association for the Study of Diabetes 50th Annual Meeting; Vienna, Austria. 2014; Session 1337, the 29th Camillo Golgi Lecture.

12. American Diabetes Association. Microvascular complications and foot care: standards of medical care in diabetes. Diab Care. 2019;42(1):S124-S138. doi:10.2337/dc19-S011

13. Sorensen L, Molyneaux L, Yue D. Insensate vs painful diabetic neuropathy: the effects of height, gender, ethnicity and glycemic control. Diab Res Clin Pract. 2002;57:45-51. doi:10.1016/S01688227(02)00010-4

14. Smith A, Singelton J. Obesity and hyperlipidemia are risk factors for early diabetic neuropathy. J Diab Complications. 2013;27(5):436442. doi:10.1016/j.jdiacomp.2013.04.003

15. Tesfaye S, Boulton AJ, Dyck PJ, et al. Diabetic neuropathies: update on definitions, diagnostic criteria, estimation of severity, and treatments. Diab Care. 2010;33:2285-2293. doi:10.2337/dc101303

16. Karsidag S, Morali S, Sargin M, Salman S. The electrophysiological findings of subclinical neuropathy in patients with recently diagnosed type 1 diabetes mellitus. Diabetic Res Clin Pract. 2005;67(3):211219. doi:10.1016/j.diabres.2004.07.017

17. Celiker R, Basgoze O, Bayraktar M. Early detection of neurological involvement in diabetes mellitus. Electromyogr Clin Neurophysiol. 1996;36:29-35. 
18. Sartucci F, Piagessi A, Logi F, et al. Impaired ascendant central pathways conduction in impotent diabetic subjects. Acta Neurol Scand. 1999;99:381-386. doi:10.1111/j.1600-0404.1999.tb07368.x

19. Hamid S, Refaat F, Kalid A, Ahmed H, Madleen A. Neuropsychological, neurophysiological and laboratory markers of direct brain injury in type 2 diabetes mellitus. J Neurol Neurosci. 2012;3(1):2.

20. Umegaki H, Makino T, Uemura $\mathrm{K}$, et al. The associations among insulin resistance, hyperglycemia, physical performance, diabetes mellitus, and cognitive function in relatively healthy older adults with subtle cognitive dysfunction. Front Aging Neurosci. 2017;9:72. doi:10.3389/fnagi.2017.00072

21. Mc Crimmon RJ, Ryan CM, Frier Bm. Diabetes and cognitive dysfunction. Lancet. 2012;379:2291-2299. doi:10.1016/S0140-6736(12) 60360-2
22. Ryan C, David F, Catrina R. Type 2 diabetes and cognitive impairment contributions from neuroimaging. J Geriatr Psychiatry Neurol. 2014;27(1):47-55. doi:10.1177/0891988713516543

23. Haque A, Polcyn R, Matzelle D, Banik N. New insights into the role of neuron-specific enolase in neuro-inflammation, neurodegeneration, and neuroprotection. Brain Sci. 2018;8:33. doi:10.3390/ brainsci8020033

24. Harini S, Bahagya V. Diabetes mellitus and cognition- a non invasive study. Int $J$ Physiol. 2019;7(3):85-90. doi:10.5958/2320608X.2019.00091.X

\section{Publish your work in this journal}

Neuropsychiatric Disease and Treatment is an international, peerreviewed journal of clinical therapeutics and pharmacology focusing on concise rapid reporting of clinical or pre-clinical studies on a range of neuropsychiatric and neurological disorders. This journal is indexed on PubMed Central, the 'PsycINFO' database and CAS, and is the official journal of The International Neuropsychiatric Association (INA). The manuscript management system is completely online and includes a very quick and fair peer-review system, which is all easy to use. Visit http://www.dovepress.com/testimonials.php to read real quotes from published authors. 